\title{
Colletotrichum siamense, $C$. theobromicola and $C$. queenslandicum from several plant species and the identification of $C$. asianum in the Northern Territory, Australia
}

\author{
R S James • J. Ray • Y. P. Tan • R. G. Shivas
}

Received: 21 January 2014 / Accepted: 7 July 2014 / Published online: 16 July 2014

(C) Australasian Plant Pathology Society Inc. 2014

\begin{abstract}
Four species, Colletotrichum asianum, C. queenslandicum, $C$. siamense and C. theobromicola, were isolated and identified from several plants species in the Northern Territory, Australia. Some of these fungal associations represent first reports, namely, C. queenslandicum on Passiflora edulis; C. siamense on Artocarpus heterophyllus, Eriobotrya japonica, Ficus carica, Mentha sp., Piper nigrum, Rosmarinus officinalis and Theobroma cacao; and C. theobromicola on Coffea canephora and C. arabica. Colletotrichum asianum was isolated from mango for the first time in the NT. These collections help provide evidence for the absence of Colletotrichum spp. of biosecurity importance in the Northern Territory.
\end{abstract}

Keywords Colletotrichum gloeosporioides species complex · Anthracnose $\cdot$ Plant health surveillance $\cdot$ biosecurity

\section{Introduction}

Colletotrichum is an important genus of plant pathogenic fungi that cause postharvest rots and anthracnose on a wide range of fruit, vegetable and ornamental hosts, especially in subtropical and tropical regions (Hyde et al. 2009a). Despite Colletotrichum spp. being collectively listed in the top 10 fungal pathogens of scientific and economic importance (Dean et al. 2012), little is known about their host interactions.

R. S. James $(\bowtie) \cdot$ J. Ray

Northern Australia Quarantine Strategy (NAQS), Australian Government Department of Agriculture, Eaton, NT0812, Australia

e-mail: rebecca.james@agriculture.gov.au

Y. P. Tan • R. G. Shivas

Plant Pathology Herbarium, Biosecurity Queensland, Department of Agriculture, Fisheries and Forestry, Dutton Park, QLD 4012, Australia
There are many accounts of Colletotrichum surviving asymptomatically on plant surfaces or as an endophyte within host tissue (Leandro et al. 2002; Damm et al. 2013; Talhinhas et al. 2011). Epiphytic and endophytic life phases and quiescent infection stages may precede a damaging necrotic phase in which lesions develop (Cannon et al. 2012), or may indicate variable virulence (Rojas et al. 2010).

In many cases, the accuracy of historical data about Colletotrichum spp. requires scrutiny with regard to host association, putative pathogenicity and pathogen identification (Hyde et al. 2009b). The identification of Colletotrichum spp. is further complicated by the lack or inaccessibility of many type specimens (Cai et al. 2009) and the occurrence of species complexes that are not easily resolved by morphological and single loci sequence approaches (Crouch et al. 2009; Damm et al. 2013; Weir et al. 2012). Since Weir et al. (2012) resolved the $C$. gloeosporioides species complex into 22 species using multi-locus phylogenies, several other novel species in this complex have been described (Peng et al. 2012; Doyle et al. 2013; Lima et al. 2013; Liu et al. 2013; Peng et al. 2013; Udayanga et al. 2013).

Accurate identification of host and knowledge of pathogen distributions are essential for making informed decisions in regard to biosecurity and disease management. The aim of this study was to examine isolates of Colletotrichum from horticultural plants in the Northern Territory (NT) in order to determine the status of species of biosecurity importance. Several species from within the C. gloeosporioides species complex were identified from various host plants collected in the NT during plant health surveillance carried out by members of the Northern Australia Quarantine Strategy (NAQS); a national program administered by the Commonwealth of Australia to detect biosecurity threats through targeted surveillance of plant pathogens, weeds and insect pests along coastal areas of northern Australia. 
Table 1 Colony morphology of representative isolates from this study

\begin{tabular}{|c|c|c|c|}
\hline Species & Colony description ${ }^{a}$ & Conidia & Isolate \\
\hline Colletotrichum asianum & $\begin{array}{l}\text { Greyish white with sparse aerial mycelium and abundant dark acervuli } \\
\text { towards the centre; reverse tinged salmon; colonies about } 7 \mathrm{~cm} \text { diam. }\end{array}$ & $\begin{array}{l}\mathrm{L}:(13) 14.0-18.5(21) \\
\quad \mathrm{W}:(4) 4.0-5.0(6)\end{array}$ & BRIP 57972a \\
\hline $\begin{array}{l}\text { Colletotrichum } \\
\text { theobromicola }\end{array}$ & $\begin{array}{l}\text { Grey with abundant tufted mycelium; abundant acervuli with orange } \\
\text { conidial masses towards the centre; reverse grey; colonies covers entire plate }\end{array}$ & $\begin{array}{l}\mathrm{L}:(12) 14.0-18.0(21) \\
\quad \mathrm{W}:(3.5) 4.0-5.0(5)\end{array}$ & BRIP 57984 \\
\hline Colletotrichum siamense & $\begin{array}{l}\text { White with dense cottony aerial mycelium; a few acervuli at the point of } \\
\text { inoculation with orange conidial masses; reverse grey to pale brown; } \\
\text { covers entire plate }\end{array}$ & $\begin{array}{l}\mathrm{L}:(12) 13.5-17.5(18) \\
\quad \mathrm{W}:(3) 3.5-5.0(5)\end{array}$ & BRIP 57976 \\
\hline $\begin{array}{l}\text { Colletotrichum } \\
\text { queenslandicum }\end{array}$ & $\begin{array}{l}\text { Grey with only very scant aerial mycelium towards the centre; entirely } \\
\text { covered with numerous, scattered acervuli that ooze orange conidial } \\
\text { masses; covers entire plate. }\end{array}$ & $\begin{array}{l}\text { L: (13) } 14.0-16.5(18) \\
\quad W:(4) 3.5-6.0(9)\end{array}$ & BRIP 57981a \\
\hline
\end{tabular}

${ }^{\mathrm{a}}$ after $10 \mathrm{~d}$ at $25^{\circ} \mathrm{C}$ under $12 \mathrm{~h}$ near ultraviolet light/12 $\mathrm{h}$ dark

\section{Materials and methods}

Sample collection

Samples were collected from hosts targeting symptoms of anthracnose. Samples were collected mostly from a tropical plant nursery at Bees Creek (33 km south east of Darwin), and a garden at Middle Point (65 km south-east of Darwin); with additional specimens from Darwin and the Tiwi Islands. Samples were surface sterilised by wiping with ethanol (95\%) soaked wipes (KimTech ${ }^{\circledR}$, Kimberly Clark, Canberra), and then moist incubated in plastic trays using paper towels soaked with sterile tap water. Plates of water agar (WA) supplemented with rifamipicin (Sigma, St Louis, Missouri) at $10 \mu \mathrm{g}$. $\mathrm{L}^{-1}$ were inoculated with a sterile needle touched onto conidial masses indicative of Colletotrichum that had formed on moist incubated plant tissue. Hyphal tip cultures were then maintained on agar plates of half-strength potato dextrose agar ( $1 \frac{1}{2} \mathrm{PDA}$ ) (Difco ${ }^{\mathrm{TM}}$, Becton Dickinson, North Ryde, NSW). Pure cultures were deposited at the Plant Pathology Herbarium, Dutton Park, Queensland (BRIP).

\section{Molecular identification}

Mycelia were scraped off 2 wk old cultures on PDA and macerated with $0.5 \mathrm{~mm}$ glass beads (Daintree Scientific, St. Helens, Tasmania, Australia) in a Tissue Lyser (Qiagen, Hilden, Germany). Genomic DNA was extracted with the Gentra Puregene DNA Extraction kit (Qiagen) according to the manufacturer's instructions. The primers V9G (De Hoog and Gerrits van den Ende 1998) and ITS4 (White et al. 1990) were used to amplify the internal transcribed spacer (ITS) region of the ribosome genes. The primers T1 (O'Donnell and Cigelnik 1997) and Bt2b (Glass and Donaldson 1995) were used to amplify part of the beta-tubulin (BT) gene. All gene regions were amplified with the Phusion High-Fidelity PCR Master Mix (New England Biolab, Ipswich, MA, USA). The PCR products were purified and sequenced by Macrogen Incorporated (Seoul, Korea) on the 3730xl DNA Analyser
(Applied Biosystems, Foster City, USA) with the amplifying primers. The ITS and BT sequences from the BRIP isolates were compared against the GenBank nucleotide database using BLASTn. A direct comparison was also made against ITS or BT sequences from ex-type cultures to verify the identification.

\section{Morphological examination}

Morphological data was collected from representative cultures of the four species: Conidia were measured after 10 days incubation at $25^{\circ} \mathrm{C}$ under $12 \mathrm{~h}$ near ultraviolet light $/ 12 \mathrm{~h}$ dark (Smith 2002) to encourage sporulation. Ranges were expressed as (min.-) mean-SD - mean+SD (-max.) with values rounded to $0.5 \mu \mathrm{m}$. Means and standard deviations (SD) were made from at least 20 measurements. Images were captured with a Leica DFC 500 camera attached to a Leica DM5500B compound microscope with Nomarski differential interference contrast.

\section{Results}

Sample collection and morphology

Colletotrichum asianum, C. queenslandicum, C. siamense and $C$. theobromicola are recorded for the first time from the Northern Territory, Australia. The four species are briefly described from symptoms (Table 1) and morphology (Fig. 1).

Fig. 1 Morphology and conidia of isolates in this study after $10 \mathrm{~d}$ incubation at $25^{\circ} \mathrm{C}$ under $12 \mathrm{~h}$ near ultraviolet light $/ 12 \mathrm{~h}$ dark. a b Colletotrichum queenslandicum (BRIP57981a) morphology and conidia from c Passiflora edulis; d- e Colletotrichum theobromicola (BRIP57984a) morphology and conidia from $\mathbf{f}$ Coffea arabica; $\mathbf{g}-\mathbf{h}$ Colletotrichum siamense (BRIP57976a) morphology and conidia from $\mathbf{i}$ Piper nigrum; $\mathbf{j}-\mathbf{k}$ Colletotrichum asianum (BRIP57972a) morphology and conidia from Mangifera indica. Scale bar for $\mathbf{a ~ d ~ g ~ j ~} \mathbf{~ c ~} \mathbf{f} \mathbf{i}=100 \mathrm{~mm} ; \mathbf{b}$ $\mathbf{e} \mathbf{h} \mathbf{k}=10 \mu \mathrm{m}$ 


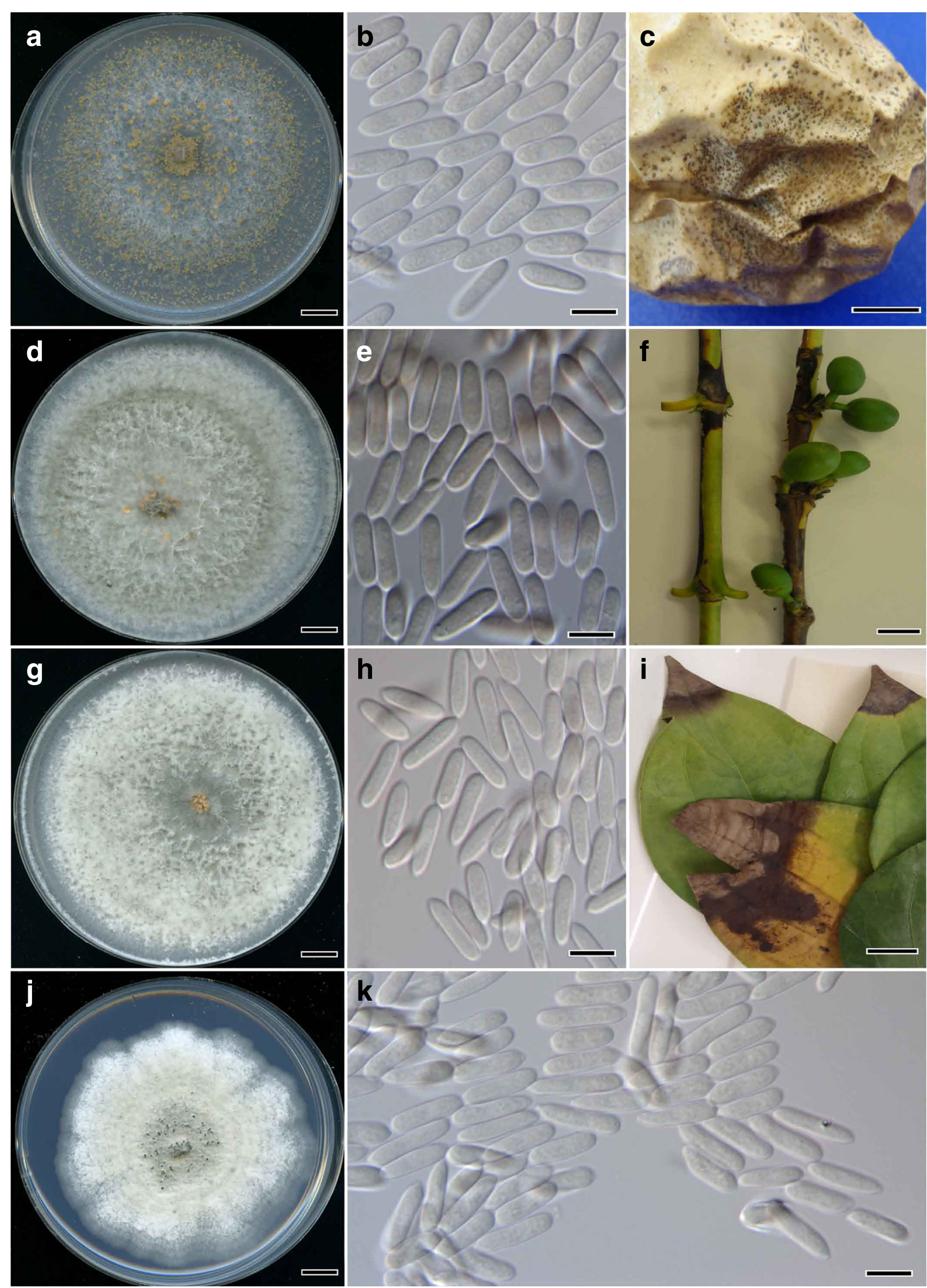


Colletotrichum theobromicola was recorded from Coffea arabica for the first time, and C. queenslandicum was recorded from Passiflora edulis for the first time. Colletotrichum siamense was isolated for the first time from eight plant species: Coffea canephora, Piper nigrum, Theobroma cacao, Ficus carica, Artocarpus heterophyllus, Eriobotrya japonica, Mentha sp. and Rosmarinus officinalis. A summary of Colletotrichum isolates identified in this study is listed in Table 2.

\section{Molecular Identification}

One isolate was identified as C. asianum based on a $100 \%$ identity to GenBank FJ972612 (ITS sequence of the ex-type strain of C. asianum CBS 130418). One isolate was identified as $C$. queenslandicum based on a $99 \%$ identity to GenBank JX010414 (BT sequence of the ex-type strain of C. queenslandicum ICMP 1778). Thirteen isolates were identified as $C$. siamense based on a $99-100 \%$ identity to GenBank JX010404 (the BT sequence of the ex-type strain of $C$. siamense CBS 130417). Finally, two isolates were identified as $C$. theobromicola based on a $99 \%$ identity to GenBank JX010294 (ITS sequence of the ex-type strain of $C$. theobromicola CBS 124945). The BRIP accession numbers and isolate details are listed in Table 2.

\section{Discussion}

Most of the isolates in this study were identified as C. siamense, which has been reported from China, USA, the African continent, Vietnam (Weir et al. 2012) and Thailand (Prihastuti et al. 2009) on a wide range of hosts. In Australia, $C$. siamense has been recorded in New South Wales and Queensland (Weir et al. 2012) but has not been previously reported from the NT. Colletotrichum siamense is thought to be geographically diverse with a wide host range (Weir et al. 2012). In this study $C$. siamense was collected numerous times at both sites southwest of Darwin and from a wide range of hosts. Of the 20 isolates of Colletotrichum identified in this study, 16 were $C$. siamense isolated from 10 of the 12 hosts examined. A majority of these hosts did not exhibit signs of disease, and consequently $C$. siamense is likely a common and widespread saprobe or endophyte.

Colletotrichum siamense is a recently described species (Prihastuti et al. 2009) in the C. gloeosporioides species complex and very little is known about its ecology and epidemiology. Consequently, it is difficult to ascertain whether these plant associations are actually first records for C. siamense. It is interesting to note that BLAST comparison of BT gene sequence data of some Colletotrichum spp. from Phoulivong et al. (2010) matched that of $C$. siamense (Weir et al. 2012). Clarifying historical records may identify many other host associations for $C$. siamense.

Table 2 A list of isolates examined in this study

\begin{tabular}{|c|c|c|c|c|c|c|}
\hline Species & Collection no. ${ }^{\mathrm{a}}$ & Host & Symptom & Locality $^{\mathrm{b}}$ & GenBank no. & \\
\hline & & & & & $\operatorname{ITS}^{\mathrm{c}}$ & BT $^{d}$ \\
\hline C. asianum & BRIP 57972a & Mangifera indica & Stem dieback & Bees Creek & KF877314 & \\
\hline C. queenslandicum & BRIP 57981a & Passiflora edulis & Fruit (postharvest) & Darwin & & KF877320 \\
\hline C. siamense & BRIP 57967b & Artocarpus heterophyllus & Asymptomatic leaf & Middle Point & & KF877321 \\
\hline C. siamense & BRIP 57977a & Artocarpus sericicarpus & Asymptomatic leaf & Bees Creek & & KF877322 \\
\hline C. siamense & BRIP 57970a & Coffea arabica & Leaf lesion & Bees Creek & & KF877323 \\
\hline C. siamense & BRIP 57963a & Coffea canephora & Asymptomatic petiole & Middle Point & & KF877324 \\
\hline C. siamense & BRIP 57964a & Coffea canephora & Asymptomatic stem & Middle Point & & KF877325 \\
\hline C. siamense & BRIP 57965a & Coffea canephora & Asymptomatic leaf & Middle Point & & KF877326 \\
\hline C. siamense & BRIP 57980a & Eriobotrya japonica & Asymptomatic leaf & Bees Creek & & KF877327 \\
\hline C. siamense & BRIP 57979a & Ficus carica & Asymptomatic leaf & Bees Creek & & KF877328 \\
\hline C. siamense & BRIP 57975a & Mentha sp. & Leaf lesion & Bees Creek & & KF877329 \\
\hline C. siamense & BRIP 57976a & Piper nigrum & Leaf lesion & Bees Creek & & KF877330 \\
\hline C. siamense & BRIP 57978a & Rosmarinus officinalis & Asymptomatic leaf & Bees Creek & & KF877331 \\
\hline C. siamense & BRIP 57966a & Theobroma cacao & Asymptomatic bud & Middle Point & & KF877318 \\
\hline C. siamense & BRIP 57966b & Theobroma cacao & Asymptomatic leaf & Middle Point & & KF877319 \\
\hline C. theobromicola & BRIP 57969a & Coffea arabica & Flower lesion & Bees Creek & KF877316 & \\
\hline C. theobromicola & BRIP 57984a & Coffea arabica & Leaf lesion & Melville Island & KF877317 & \\
\hline
\end{tabular}

${ }^{\mathbf{a}}$ BRIP: Plant Pathology Herbarium, Dutton Park, Queensland, Australia; ${ }^{\mathbf{b}}$ Locality in the Northern Territory; ${ }^{\mathbf{c}}$ internal transcribed spacer region; ${ }^{\mathbf{d}}$ beta-tubulin 
Colletotrichum asianum was isolated from Mangifera indica with stem dieback and mummified fruit. It was not confirmed if the isolate was the cause of the stem dieback although $C$. asianum is associated with fruit rots (Weir et al. 2012). This finding represents the first identification of C. asianum in the NT. Colletotrichum asianum is commonly recorded on $M$. indica with records from Australia (New South Wales), Columbia, Japan, Panama, Philippines (Weir et al. 2012) and Thailand (Phoulivong et al. 2010).

Colletotrichum queenslandicum was recorded on P. edulis from fruit showing symptoms of postharvest anthracnose. This specimen was collected from a plant that may have been imported from interstate. This species was first isolated from Carica papaya in Queensland, where it was originally named C. gloeosporioides var. minor (Simmonds 1968), but is now accepted as a unique species (Weir et al. 2012). Colletotrichum queenslandicum has also been reported from Fiji (Weir et al. 2012).

Colletotrichum theobromicola was first described from T. cacao by Delacroix (1905). As the type specimen was not located, a neotype was proposed by Rojas et al. (2010). Colletotrichum theobromicola has been recorded in Australia (New South Wales and Queensland), Israel, Mexico, New Zealand, Panama and USA (Weir et al. 2012). This species is a known pathogen on Stylosanthes, Fragaria and T. cacao (Rojas et al. 2010, Weir et al. 2012). In this study, C. theobromicola was identified from two plants of C. arabica from geographically different locations and associated with plant disease symptoms. This finding represents the first identification of $C$. theobromicola from Coffea arabica. Further investigation into the epidemiology of this isolate was beyond the scope of our study, but of note is that one of the host plants had anthracnose-like lesions on the stem. This plant was situated in the shade and sampled near the end of the wet season (Mar.). The second plant exhibited symptoms of anthracnose on leaves, stems and flowers, and was growing in full sun at the end of the dry season (Oct.). Koch's postulates were not completed and currently there is no evidence in the literature that indicates $C$. theobromicola is a pathogen of coffee.

This work has expanded the distribution and host range of four species from the $C$. gloeosporioides species complex; C. asianum, C. queenslandicum, C. siamense and $C$. theobromicola. The identification of these species alone provides background information for biosecurity risk assessment processes. Unravelling the ecology and host interactions of these fungi will eventually lead to a better understanding of the role these species play as pathogens, with consequent improved disease management and biosecurity outcomes.

Acknowledgments The authors would like to acknowledge the support and funding by NAQS. Projects like these help to provide valuable information for managing Australia's biosecurity.

\section{References}

Crouch JA, Clarke BB, Hillman BI (2009) What is the value of ITS sequence data in Colletotrichum systematics and species diagnosis? A case study using the falcate-spored graminicolous Colletotrichum group. Mycologia 101:648-656

Cai L, Hyde KID, Taylor PWJ, Weir BS, Waller JM, Abang MM, Zhang JZ, Yang YL, Phoulivong S, Liu ZY, Prihastuti H, Shivas RG, McKenzie EHC, Johnston PR (2009) A polyphasic approach for studying Colletotrichum. Fungal Diversity39:183-204

Cannon PF, Damm U, Johnston PR, Weir BS (2012) Colletotrichum status and future directions. Studies in Mycology 73:181-213

Damm U, Cannon PF, Liu F, Barreto RW, Guatimosim E, Crous PW (2013) The Colletotrichum orbiculare species complex: Important pathogens of field crops and weeds. Fungal Diversity 61:29-59

De Hoog GS, Gerrits van den Ende AHG (1998) Molecular diagnostics of clinical strains of filamentous basidiomycetes. Mycoses 41:183189

Dean R, Van Kan JAL, Pretorius ZA, Hammond-Kosack KE, Di Pietro A et al (2012) The Top 10 fungal pathogens in molecular plant pathology. Mol Plant Pathol 13:414-430

Delacroix G (1905) Travaux de la Station de Pathologie Vegétalé. II: Champignons parasites de plants cultivées dans les région chaudes. Bulletin de la Société Mycologique de France 21(3):191-204

Delacroix (1905) Champignons parasites de plants cultivées dans les région chaudes, Bulletin de la Société Mycologique de France 21: 191

Doyle VP, Oudemans PV, Rehner SA, Litt A (2013) Habitat and host indicate lineage identity in Colletotrichum gloeosporioides $\mathrm{s}$. 1. from wild and agricultural landscapes in North America. PLoS One 8: e62394

Glass NL, Donaldson G (1995) Development of primer sets designed for use with PCR to amplify conserved genes from filamentous ascomycetes. Applied Environmental Microbiology 61:1323-1330

Hyde KD, Cai L, Cannon PF, Crouch JA, Crous PW, Damm U, Goodwin PH, Chen H, Johnston PR, Jones EBG, Liu ZY, McKenzie EHC, Moriwaki J, Noireung P, Pennycook SR, Pfenning LH, Prihastuti H, Sato T, Shivas RG, Tan YP, Taylor PWJ, Weir BS, Yang YL, Zhang JZ (2009a) Colletotrichum - names in current use. Fungal Divers 39:147-182

Hyde KD, Cai L, McKenzie EHC, Yang YL, Zhang J, Prihastuti H (2009b) Colletotrichum: a catalogue of confusion. Fungal Divers 39:1-17

Leandro LFS, Gleason ML, Wegulo SN, Nutter FW Jr (2002) Survival and sporulation of Colletotrichum acutatum on symptomless strawberry leaves. Acta Horticult 567:627-629

Lima NB, De Batista MV, De Morais MA, Barbosa MAG, Michereff SJ, Hyde KD, Câmara MPS (2013) Five Colletotrichum species are responsible for mango anthracnose in northeastern Brazil". Fungal Divers 61(1):75-88

Liu F, Damm U, Cai L, Crous PW (2013) Species of the Colletotrichum gloeosporioides complex associated with anthracnose diseases of Proteaceae". Fungal Divers 61(1):89-105

O’Donnell K, Cigelnik E (1997) Two divergent intragenomic rDNA ITS2 types within a monophyletic lineage of the fungus Fusarium are nonorthologous. Molecular Phylogenetic Evolution 7:103-116

Peng LJ, Yang Y, Hyde KD, Bahkali AH, Liu Z (2012) Colletotrichum species on Citrus leaves in Guizhou and Yunnan provinces, China. Cryptogam Mycol 33:267-283

Peng LJ, Sun T, Yang YL, Cai L, Hyde KD, Bahkali AH, Liu ZY (2013) Colletotrichum species on grape in Guizhou and Yunnan provinces, China. Mycoscience 54:29-41

Phoulivong S, Cai L, Chen H, McKenzie EHC, Abdelsalam K et al (2010) Colletotrichum gloeosporioides is not a common pathogen on tropical fruits. Fungal Divers 44:33-43 
Prihastuti S, Cai L, Chen H, McKenzie EHC, Hyde KD (2009) Characterization of Colletotrichum species associated with coffee berries in northern Thailand. Fungal Divers 39:89-109

Rojas EI, Rehner SA, Samuels GJ, Van Bael SA, Herre EA et al (2010) Colletotrichum gloeosporioides s.1. associated with Theobroma cacao and other plants in Panama: multilocus phylogenies distinguish host-associated pathogens from asymptomatic endophytes. Mycologia 102(6):1318-1338

Simmonds JH (1968) Type specimens of Colletotrichum gloeosporioides var. minor and Colletotrichum acutatum. Queensland Journal of Agricultural and Animal Sciences 25 (3) :178

Smith D (2002) Culturing, preservation and maintenance of fungi. In: Waller JM, Lenné JM, Waller SJ (eds) , Plant Pathologist's Pocketbook. 3rd ed. CAB Publishing, UK, pp 384-409
Talhinhas P, Mota-Capita C, Martins S, Ramos AP, Neves-Martins $J$ et al (2011) Epidemiology, histopathology and aetiology of olive anthracnose caused by Colletotrichum acutatum and C. gloeosporioides in Portugal Olive anthracnose in Portugal. Plant Pathol 60(3):483-495

Udayanga D, Manamgoda DS, Liu X, Chukeatirote E, Hyde KD (2013) What are the common anthracnose pathogens of tropical fruits? Fungal Divers 61(1):165-179

Weir B, Johnston PR, Damm U (2012) The Colletotrichum gloeosporioides species complex. Stud Mycol 73:115-180

White TJ, Bruns T, Lee S, Taylor J (1990) Amplification and direct sequencing of fungal ribosomal RNA genes for phylogenetics. In: PCR protocols: A guide to methods and applications. Innis MA, Gelfand DH, Sninsky JJ, White TJ (eds.) Academic Press, New York. pp. 315-322 